DOI https://doi.org/10.18551/rjoas.2018-12.10

\title{
STRATEGY COMPILE FOR CLUSTER OF BATIK TULIS WARNA ALAM SMALL INDUSTRIES: OPPORTUNITY, THREAT AND STRATEGY
}

\author{
Sugiarto Meilan*, Kusmantini Titik, Jayadianti Herlina, Utami Yekti \\ Universitas Pembangunan Nasional "Veteran" Yogyakarta, Indonesia \\ *E-mail: msugiarto89@gmail.com
}

\begin{abstract}
Drafting the strategy involves internal factors and external factors is the way to develop a cluster of small Batik industries natural colors Kebon, Klaten Regency, Central Java. Drafting the strategy done with SWOT analysis approach. Identify the strengths and weaknesses as internal factors as well as opportunities and challenges as the external factors are very important. Because this will help determine the strategic step for Small Industrial based Cluster to face the challenges and grab the opportunity by strengthening the strengths and minimize the weaknesses.
\end{abstract}

\section{KEY WORDS}

SWOT, small industrial cluster, strategy, batik the natural color.

The vision of Klaten Regency is realizing a city forward, independent and competitive power with one strategic mission is the empowerment of the competitiveness of small and medium industry-based cluster. One of the cluster of small industry flagship Klaten i.e. small Batik industries cluster with natural colors. This became one of the flagship products typical of the Klaten Regency. Empowerment and strengthening the cluster-based industry can increase competitiveness in the era of the ASEAN economic community, where the challenges of business competition is getting heavier and require more governance professionals. This is one of the alternatives assessed right in an attempt to boost the local economy because of Indonesia's small and medium industries already proven as one of the supporters of the economy that is able to survive during the economic crisis. A significant small industry contributions towards the country will strengthen the country's economy in the long run. Since the year 2010 have been mapped the potential of small and medium industrial cluster. Medium-term Regional development plan 2015-2020 Klaten Regency is the excellence cluster-based economy and agropolitan. The goal was to improve and develop the regional economy more productive, creative, innovative and competitive power based on the people's economy based on local potential. With the construction of the local economy are expected to stimulate the opening of local employment opportunities in the region in sectors that make use of human resources, natural, institutional and local (Blakely and Bradshaw, 2002). The emphasis on the utilization of local resources and the use as a competitive advantage is an interesting issue, both in the academic field as well as practical (Barney, 2001). The local Government of Klaten Regency alignments against the small Batik industries is manifested in the form of the assignment policies over the implementation of the working uniform of Batik on Thursday and Friday for its officers. The policy is expected to boost the growth of small industries of Batik, which can further improve the competitiveness of business entities ranging from craftsman, trader up to tailor business group. Another policy in the form of the people's business credit programs with low interest rates and without collateral and programs Division of the card business license for medium and small businesses in the Klaten Regency.

Characteristics of small industries in Indonesia as stated in Act No. 20 of the year 2008 with the term small business, namely economic productive effort that stands on its own, which is done by the individual or business entity that is not a subsidiaries or branches of the company not owned, controlled or being part of either directly or indirectly from medium or large businesses. On the basis of wealth and yield sales, an industry belongs to the category 
of small industries if it has a wealth of 50 up to 500 million with sales of 300 million sales results up to 2.5 billion.

Every small industry as a company face many opportunities and challenges that will interact with the strengths and weaknesses that are owned small industries. Identify internal strengths and weaknesses, and external opportunities and challenges, also known as SWOT analysis. The length of the SWOT strengths, industry, opportunities and threats (Swapna, 2018). There is no list of standards relating to the essential factors that apply to all companies due to its special (Houben et al., 1999). The study was done because there has been no specific study with a focus on small Batik industries cluster Color Natural Kebon, Klaten Regency, Central Java, Indonesia by using SWOT analysis approach. A study done by identifying strengths and weaknesses as well as opportunities and challenges facing the small industry cluster using SWOT analysis.

Drafting the strategy is done to determine a strategy based on an analysis of internal factors and the factors ekternal the object of research. Drafting the strategy conducted using SWOT analysis approach, covering strengths, weaknesses, opportunities and challenges facing an object of research. The SWOT analysis is used to identify the strengths and weaknesses of an organization as well as the opportunities and challenges faced by organizations that appeared from the environment. The next strategy was developed to build on strengths, eliminate weaknesses, take advantage of opportunities or challenges. The strengths and weaknesses identified by assessing the internal conditions and opportunities as well as challenges with assessing the condition of the ekternal organization. Internal assessment test all aspects of the Organization, such as human resources, facilities, locations, products and services, in order to identify the strengths and weaknesses of the organization.

Table 1 - SWOT Matrix (Ghazinoory et al., 2011)

\begin{tabular}{|c|c|c|}
\hline $\mathrm{n} / \mathrm{n}$ & Strengths & Weaknesses \\
\hline Opportunities & SO Strategies & WO \\
\hline Threats & ST & WT \\
\hline
\end{tabular}

Strength-Opportunity strategies using internal forces the company to take advantage of opportunities. The marketers will usually like in position using the internal strength to capitalize on trends and external event (Lane and Piercy, 2009). Weakness-Opportunity strategies geared to improve internal weaknesses by utilizing external opportunities. Sometimes opportunities arise demanding the improvement of a company's internal weaknesses if like to exploit it. Strength-Threat strategy used a company to reduce the impact of external challenges. This does not mean that a strong organization will always be dealing directly with the challenges in the external environment. In addition, by adjusting the internal factors with external Weakness, strategies - Threat is enduring tactics directed by reducing internal weaknesses and avoid external challenges (Hunger and Wheelan, 2011)

\section{METHODS OF RESEARCH}

Batik industry with natural colors located at Kebon, Klaten Regency, Central Java. There are 19 batik craftsmen who are members of the cluster which become respondents in this research. Sri Windarti was the Chairman of the Association. Data collection research using a questionnaire with structured model with score likert scale using the respondents answer 5 points. For the preparation of the strategy for object research, research data obtained further analyzed using SWOT analysis.

\section{RESULTS OF STUDY}

The following are the highest average rating from the results of the identification and assessment of batik artisans group natural colors Kebon Klaten Regency against internal 
factors (strengths and weaknesses) are shown in table 2 and the average value of the highest factor (include opportunities and challenges) are shown in table 3.

Table 2 - Means Value of Internal Factors

Identification of Internal factors: Strength vs. Weakness

\begin{tabular}{|l|}
\hline \multicolumn{1}{|c|}{ Strength } \\
\hline Has a varied motives \\
\hline Natural coloring \\
\hline Marketing associations exist a wide \\
\hline Has a competitive price \\
\hline Accept orders \\
\hline Has a Geobatik as a characteristic \\
\hline Good packaging \\
\hline Solid group \\
\hline
\end{tabular}

\begin{tabular}{|l|}
\hline \multicolumn{1}{|c|}{ Weakness } \\
\hline Weak promotion. \\
\hline Less utilizing information technology \\
\hline $\begin{array}{l}\text { Management and business administration have not been } \\
\text { fullest. }\end{array}$ \\
\hline Have no patents and intellectual property yet \\
\hline
\end{tabular}

Identification of external factors: Opportunities vs. Challenge

\begin{tabular}{|l|l|l|}
\hline \multicolumn{1}{|c|}{ Opportunities } & \multicolumn{1}{c|}{ Challenge } \\
\hline Increasing order & \multicolumn{1}{|c|}{\begin{tabular}{l|} 
many imported products \\
\hline The extent of market opportunity
\end{tabular}} & $\begin{array}{l}\text { competition of similar products of high } \\
\text { technology in marketing. }\end{array}$ \\
\hline Application IT is increasingly easy to developed. & $\begin{array}{l}\text { unstable economic conditions } \\
\text { the existence of local government support for the } \\
\text { development of small and medium industry }\end{array}$ \\
\hline
\end{tabular}

\begin{tabular}{|c|c|c|}
\hline No. & Internal Factors & Mean Value \\
\hline \multirow[t]{10}{*}{1.} & Strengths & \\
\hline & Excellent products & 4.74 \\
\hline & Varied motives & 4.42 \\
\hline & Using natural dyes & 4.47 \\
\hline & Solid Group / community & 3.00 \\
\hline & Marketed in other areas & 4.21 \\
\hline & Good Packaging & 2.95 \\
\hline & Good Price & 4.84 \\
\hline & Accept Order & 3.79 \\
\hline & Has a Geobatik as a characteristic & 3.16 \\
\hline \multirow[t]{5}{*}{2.} & Weaknesses & \\
\hline & Weak promotion. & 2.16 \\
\hline & Less utilizing information technology & 3.47 \\
\hline & Management and business administration have not been fullest. & 2.47 \\
\hline & Have no patents and intellectual property yet & 2.25 \\
\hline
\end{tabular}

Table 3 - Means Value of External Factors

\begin{tabular}{|l|l|c|}
\hline No. & \multicolumn{1}{|c|}{ External Factors } & Mean Value \\
\hline 1. & Opportunity & \\
\hline \multirow{8}{*}{} & Increasing order & 4.32 \\
\cline { 2 - 3 } & The extent of market opportunity & 4.53 \\
\cline { 2 - 3 } & Application IT is increasingly easy to developed. & 3.89 \\
\cline { 2 - 3 } & $\begin{array}{l}\text { the existence of local government support for the development of small and medium } \\
\text { industry }\end{array}$ & 4.16 \\
\hline $2 . \quad$ Threat & 2.53 \\
\hline \multirow{2}{*}{2} & many imported products & 2.84 \\
\cline { 2 - 3 } & competition of similar products of high & 2.95 \\
\cline { 2 - 3 } & competitors are already using information technology in marketing. & 3.26 \\
\cline { 2 - 3 } & unstable economic conditions & \\
\hline
\end{tabular}

Based on table 2, batik the natural color is the main strength of this research object. In addition, the use of natural dyes, the motives vary, and it is marketed to the outside area can also be used as power to the object of research. The limitations of knowledge in utilizing information technology is a major weakness followed by limitations in management and 
business administration. Table 3 shows that the main opportunity for the object of the research is the market is still wide open and the presence of increased product demand. Unstable economic conditions is a major challenge which is followed by the utilization of information technology by competitors in marketing its products. Based on table 2, batik the natural color as superior product is the main strength of this research object. In addition, the use of natural dyes, the motives vary, and it is marketed to the outside area can also be used as power to the object of research. While the limitations of knowledge in utilizing information technology is a major weakness followed by limitations in management and business administration. Table 3 shows that the main opportunity for the object of the research is the market is still wide open and the presence of increased product demand. Unstable economic conditions is a major challenge which is followed by the utilization of information technology by competitors in marketing its products.

Table 4 - Strategy Compile Based On SWOT Analysis

SWOT analysis: interaction between Power and opportunities

\begin{tabular}{|l|l|}
\hline Strengths & SO Strategies \\
\hline $\begin{array}{l}\text { Varied motives; Using natural dyes; Solid Group / community; } \\
\text { Marketed in other areas; Good Packaging; Good Price; Accept Order; }\end{array}$ & $\begin{array}{l}\text { Increases production capacity. } \\
\text { Has a Geobatik as a characteristic }\end{array}$ \\
\hline Opportunities & \\
\hline Many imported products & \\
Competition of similar products of high \\
Competitors are already using information technology in marketing. \\
Unstable economic conditions
\end{tabular}

SWOT analysis: interaction between the strengths and Challenges

\begin{tabular}{|l|l|}
\hline Strengths & ST Strategies \\
\hline $\begin{array}{l}\text { Varied motives; Using natural dyes; Solid Group / community; } \\
\text { Marketed in other areas; Good Packaging; Good Price; }\end{array}$ & $\begin{array}{l}\text { Online marketing } \\
\text { Accept Order; Has a Geobatik as a characteristic }\end{array}$ \\
\cline { 1 - 1 } Threats & \\
\cline { 1 - 2 } Many imported products & \\
Competition of similar products of high & \\
Competitors are already using information technology in marketing. & \\
Unstable economic conditions & \\
\hline
\end{tabular}

SWOT analysis: interaction between the weaknesses and Opportunities

\begin{tabular}{|c|c|}
\hline Weaknesses & WO Strategies \\
\hline $\begin{array}{l}\text { Weak promotion. } \\
\text { Less utilizing information technology } \\
\text { Management and business administration have not been fullest. } \\
\text { Have no patents and intellectual property yet }\end{array}$ & \multirow[t]{3}{*}{$\begin{array}{l}\text { Improve promotion } \\
\text { Increasing knowledge of information } \\
\text { technology. }\end{array}$} \\
\hline Opportunities & \\
\hline $\begin{array}{l}\text { Increasing order } \\
\text { The extent of market opportunity } \\
\text { Application IT is increasingly easy to developed. } \\
\text { the existence of local government support for the development of } \\
\text { small and medium industry }\end{array}$ & \\
\hline
\end{tabular}

SWOT analysis: interaction between the weaknesses and Challenges

\begin{tabular}{|c|c|}
\hline Weaknesses & WT Strategies \\
\hline $\begin{array}{l}\text { Weak promotion. } \\
\text { Less utilizing information technology } \\
\text { Management and business administration have not been fullest. } \\
\text { Have no patents and intellectual property yet } \\
\text { Threats }\end{array}$ & \multirow[t]{2}{*}{$\begin{array}{l}\text { Strengthen management and business } \\
\text { administration } \\
\begin{array}{l}\text { Patented a new motif as the } \\
\text { characteristics }\end{array}\end{array}$} \\
\hline $\begin{array}{l}\text { Increasing order } \\
\text { The extent of market opportunity } \\
\text { Application IT is increasingly easy to developed. } \\
\text { the existence of local government support for the development of } \\
\text { small and medium industry }\end{array}$ & \\
\hline
\end{tabular}




\section{CONLUSION}

Small industries should he opportunities and challenges. The condition cannot be avoided any longer, therefore recognizing factors of organization is essential to face the opportunities and challenges. SWOT Snalisis used to know the strengths and weaknesses of the analysis results are used in the preparation of a strategy for the industry. The SWOT analysis is done by the identification of internal and external factors which were then carried out an assessment to determine the average score each factor. Based on the average score obtained, for both internal and external factors of the object of study, shows that internal power is owned by the main product produced is a superior product, whereas the main internal weaknesses is the limitation of knowledge in utilizing information technology. On the other hand, the market is still wide open is the main opportunity with a major challenge is the country's economic conditions are not stable.

The interaction between the weaknesses with the opportunities and challenges to strategize WO and WT. As for the results of the drafting of the strategy with the SWOT analysis has been performed in this study suggests a strategy SO that it can be used is to increase the production and adoption of information technology. For strategy ST can be used is to apply online marketing, increase the intensity following the exhibition, and strengthen the Association. While the strategy WO can be used is to enhance the promotion and increase of knowledge about information technology, and to the strategy of WT can be used is to strengthen the management and administration of business and register a motif characterizes (geobatik) to obtain patent/intellectual property.

The effects of the strategy that has been compiled against the performance of the cluster of small industry become the objects in this study will be known once implemented. Therefore, in future evaluation strategy is needed to find out the effect as a form of feedback from the results of the drafting of the strategy that has been done in this study. Thus, a small industry group will be able to determine which strategies are effective and ineffective in reaching for opportunities and overcome challenges that emerge from the external environment.

\section{REFERENCES}

1. Barney, 2001. Is the Resouce Based View a Useful Perspective for Strategic Management Research? Yes. Academy of ManagementReview 26 (1), pp. 41-56.

2. Blakely, E.J., and Bradshaw, T.K. 2002. Planning Local Economooic Development: Theory and Practice, 3rd edition. Sage Publication, Inc.United Kingdom.

3. Coman, A., and B. Ronen. 2009. Focused SWOT: Diagnosing critical strengths and weaknesses. International Journal of Production Research 47 (20), pp.5677-5689.

4. Dyson, R.G.2004. Strategic development and SWOT analysis at the University of Warwick. European Journal of Operational Research 152, pp. 631-640.

5. Ghazinoory, S., M. Abdi, M. Azadegan-Mehr. 2011. Swot Methodology: A State-Of-TheArt Review For The Past, A Framework For The Future. Journal of Business Economics and Management 12 (1), pp.24-48.

6. Hitt, M.A., 2011. Strategic management: Competitiveness and Globalization: Concepts. Ninth Edition.USA: South-Western Cengage Learning.

7. Houben, G., 1999. A knowledge-based SWOT-analysis system as an instrument for strategic planning in SME sized enterprises. Decision Support Systems 26, pp. 125-135.

8. Hunger, J.D., 2011. Essentials of Strategic Management. NJ: Pearson Education.

9. Lane, N., 2009. Strategizing the sales organization. J. of Str. Marketing 17, 307-322.

10. Moser, C. 1998. The asset vulnerability framework: Reassessing urban poverty reduction strategies. World Development 26(1), pp. 1-19.

11. Reed, D. 2013. SWOT your way to the future. Industrial Management 55(2), pp.23-26.

12. Swapna, B. 2018. Cultivation and Marketing of Tuberose Flowers by the Rural Poor: An Approach of Swot Analysis. Int. J. of Agriculture, Env. and Biotech. 11(1), pp.137-140.

13. Undang-Undang Republik Indonesia Nomor 20 tahun 2008. 